\title{
KOSEP DIRI PEREMPUAN DI PERSIMPANGAN BUDAYA DALAM AUTOBIOGRAFI STUPEUR ET TREMBLEMENTS KARYA AMÉLIE NOTHOMB
}

\author{
Yeni Artanti \\ Universitas Negeri Yogyakarta \\ email: yenarta@uny.ac.id
}

\begin{abstract}
Abstrak
Identitas atau konsep diri merupakan representasi seseorang. Konsep diri pengarang dapat direkonstruksi pembaca melalui karya-karyanya, salah satunya autobiografi. Penelitian ini bertujuan mendeskripsikan konsep diri perempuan di persimpangan budaya, mencakup gambaran diri, harga diri, dan harapan diri. Sumber data penelitian ini adalah roman autobiografi Stupeur et Tremblements karya Amélie Nothomb. Penelitian ini merupakan penelitian kualitatif deskriptif dengan teknik analisis interpretatif. Pengumpulan data dilakukan dengan teknik membaca, mencatat, mengklasifikasikan, dan mengkoding. Hasil penelitian menunjukkan adanya konsep diri sebagai berikut. Pertama, kegagalan usaha peleburan diri tokoh Aku atau Amélie, sosok perempuan Belgia terdidik, menguasai bahasa Jepang dan diterima bekerja di Perusahaan Yumimoto sebagai penerjemah Jepang-Belgia/Prancis, namun terpaksa harus menerima dirinya diperkerjakan sebagai pembersih toilet, agar diterima dan melebur sebagai seorang Jepang. Dia mencoba menghapus dirinya dan mencoba melebur dalam cara pikir dan budaya Jepang, tempat ia dilahirkan dan tumbuh sampai usia lima tahun. Kedua, self-esteem atau harga diri yang selalu direndahkan oleh atasannya, wanita Jepang bernama Mori Fubuki, Saito dan Omichi. Hal itu berbenturan dengan keyakinan dan penilaian dirinya sebagai perempuan yang tumbuh di Barat. Ketiga, ideal self tokoh Amélie di Jepang yang tidak tercapai. Tokoh ini mengalami self-discrepancies, yaitu harapan dirinya berbeda dengan kenyataan. Pada akhirnya ia dapat mengaktualisasikan diri menjadi penulis setelah kembali ke Belgia.
\end{abstract}

Kata Kunci: identitas, feminisme, barat-timur, autobiografi, konsep diri

\section{WOMEN'S SELF-CONCEPT IN CULTURAL JUNCTION IN AMÉLIE NOTHOMB'S STUPEUR ET TREMBLEMENTS AUTOBIOGRAPHY}

\begin{abstract}
Identity is closely related to self-concept. Through an autobiography, authors reconstruct their concepts through their works. This study is aimed at describing women's self-concepts in a cross-cultural setting which includes their self-images, self-esteem, and self-ideals. The main source of this study is "Stupeur et Tremblements", an autobiography written by Amélie Nothomb. This study is a
\end{abstract}


descriptive qualitative research using interpretive analysis techniques. Data collection is done by reading, collecting, classifying, and coding. The results show that selfconcepts consist of (1) dissolution of selves marked by the figure of 'I' as Amélie, a Belgian woman, 22 years, educated, mastering Japanese, accepted to work at Yumimoto as a Japanese-French translator but working as toilet janitor in this company. She tried to fuse into the Japanese way of thinking and culture, the country where she was born and grew until she was five years old; (2) her self-esteem is always demeaned by his direct supervisor, a Japanese woman named Mori Fubuki and also Omichi. It clashes with her beliefs and considerations as a woman who grew up as a Western woman; and (3) Amélie's ideal self in Japan was disapproved because she faced self-discrepancies and pushed her to return to Belgium and became a successful writer.

Keywords: identity, feminism, east-west, autobiography, self-concept

\section{PENDAHULUAN}

Identitas merupakan ciri dan karakteristik seseorang yang dikaitkan dengan lingkungan sosialnya dan peranperannya baik di masa lalu, masa kini, ataupun diprojeksikan untuk masa datang yang membentuk suatu konsep diri (Oyserman, Elmore, \& Smith, 2012). Konsep diri merupakan hal penting bagi semua orang. Manusia perlu mengidentifikasikan dirinya sendiri untuk menunjukkan keberadaannya. Bagaimana manusia mendefinisikan dirinya sendiri menarik untuk dikaji misalnya melalui karya sastra, salah satunya autobiografi. Melalui fragmen kehidupan yang tertulis dalam autobiografi, penulis seolah-olah 'membuka' dirinya untuk dimaknai oleh pembaca. Transaksi kebermaknaan narasi identitas diri dalam karya autobiografi tidak bisa terjadi ketika pembacaan dilakukan secara sepintas saja. Untuk itu, diperlukan pengkajian dan penelitian.

Autobiografi merupakan suatu genre karya sastra berbentuk prosa tentang masa lalu penulis yang dituliskannya sendiri. Autobiografi berasal dari kata 'auto' berarti sendiri, 'bio' berarti hidup atau kehidurpan dan 'grafi' berarti tulisan. Autobiografi menunjuk pada sebuah roman yang ditulis oleh pengarang untuk menggambarkan perjalanan kehidupan pribadinya, termasuk wilayah psikologisya, berupa perasaan, pikiran, keyakinan, dan ideologi yang dianutnya (Sayuti, 2019). Autobiografi adalah narasi retrospektif berbentuk prosa tentang eksistensi diri penulis pada waktu tertentu dalam rentang sejarah kepribadiannya (Lejeune, 1996). Jadi, autobiografi merupakan fragmen atau penggalan kehidupan pengarang yang dikemas dan dituliskan olehnya sebagai suatu cerita. Salah satu pengarang autobiografi berbahasa Prancis (berkebangsaan Belgia) yang terkenal adalah Amélie Nothomb.

Amélie Nothomb adalah seorang Belgia dan penulis berbahasa Prancis/ francophone, lahir tanggal 13 Agustus 
1967 di Kobé, Jepang. Ayahnya seorang ambasador Belgia bernama Patrick Nothomb. Dia melewatkan masa kecilnya selama lima tahun di desa yang terletak di pegunungan Shukugawa sebelum kemudian harus berpindah mengikuti ayahnya ke China, Amerika, Bangladesh, Burma, Inggris, Laos, dan kembali ke Belgia ketika Amélie berusia 17 tahun. Amélie Nothomb kuliah di bidang Ilmu-ilmu Kemanusiaan di Institut Marie Immaculate Montjoie Uccle, Belgia. Kemudian melanjutkan kuliahnya dengan mempelajari filologi di Université Libre du Bruxelles/ Free University of Brussels dimana ia mempelajari bahasa Yunani-Latin pada waktu itu. Amélie Nothomb fasih berbahasa dan tahun 1989 kembali ke Jepang dan belajar kembali bahasa Jepang, bahasa masa kecilnya. Tahun 1990 diterima bekerja di salah satu perusahaan ternama sebagai penerjemah bahasa Prancis/Belgia - Jepang (amelienothomb.com). Sekembalinya dari Jepang, yaitu tahun 1991, mulai menulis roman pertamanya berjudul Hygene de l'Assassin yang diterbitkan satu tahun kemudian dan mendapat penghargaan Prix René-Fallet dan Prix Alain-Fournier. Sejak kesuksesan roman pertamanya tersebut, Amélie berhasil menerbitkan roman-romannya dan sampai tahun 2019, telah menghasilkan karya kuranglebih 35 karya. Selain produktif, Amélie juga berhasil mendapat penghargaan atas karya-karyanya yang dituliskannya.

Salah satu roman best seller Amélie Nothomb yang diterbitkan oleh Albin Michel tahun 1999 berjudul Stupeur et Tremblements. Roman ini mendapat penghargaan bergensi kesastraan Prancis
'Grand Prix' dari Accademie Francaise pada tahun 1999. Berdasarkan wawancara yang dilakukan Marianne Payot (2018) terhadap Amélie Nothomb, karya Stupeur et Tremblements telah diterjemahkan ke dalam 46 bahasa. Dalam bahasa Inggris diterjemahkan oleh Adriana Hunter pada tahun 2001, dicetak oleh St. Martin's Press, Amerika dengan judul Fear and Trembling atau "Takut dan Gemetar."

Sejak diterbitkan, beberapa penelitian telah dilakukan terhadap roman ini, antara lain penelitian Peter Cowley berjudul Translation and Translators in Amélie Nothomb's Autobiographical Fiction, diterbitkan melalui Australian Journal of French Studies (2011). Penelitian ini mengkaji lima karya autobiografi Amélie Nothomb yaitu Le Sabotage amoureux (1993); Stupeur et tremblements (1999); Métaphysique des tubes (2000); Biographie de la faim (2004); and Ni d'Eve ni d'Adam (2007). Penelitian tersebut menjelaskan keterkaitan figur translator/penerjemah dalam konteks generik yang merupakan representasi Nothomb sebagai penulis.

Penelitan bandingan dilakukan oleh Corina da Rocha Soares berjudul Dissociation Mentale De La Realite Extension Du Domaine De La Lutte Versus Stupeur Et Tremblements, dipublikasikan melalui jurnal Intercâmbio pada tahun 2012. Penelitian ini membandingkan disosiasi mental sebagai suatu ekstensi realitas dalam dua roman yaitu Domaine de la Lutte karya Michel Houellebecq dan Stupeur Et Tremblements karya Amélie Nothomb. Kedua roman memberikan pemahaman tentang perspektif kehidupan yang berbeda yang menjadi ciri khas masing-masing penulis. Domaine 
de la Lutte karya Houellebecq dijelaskan sebagai ekstensi realitas mental menuju kebinasaan, depresif, memunculkan humor dan ironi untuk menggambarkan keterasingan dengan 'humor hitam' atau 'tawa kuning' / dalam bahasa Inggris disebut sniffer yang sering kali merugikan orang lain. Sementara dalam Stupeur et Tremblements karya Amélie Nothomb merupakan gambaran pemisahan realitas mental menuju keselamatan, optimisme, menggunakan humor dan ironi untuk pencerahan bagi dirinya.

Penelitian lain berbentuk skripsi, yang tidak diterbitkan, dilakukan oleh Isna Fatmawati tahun 2015 yang fokus penelitiannya pada struktur cerita dan eksistensi tokoh utamanya. Sedangkan terkait identitas diri perempuan tokoh utama dalam roman Stupeur et Tremblements karya Amélie Nothomb, sejauh penelusuran peneliti, belum pernah dilakukan. Untuk itu, penelitian ini difokuskan pada identitas diri atau self-identity tokoh utama yaitu perempuan barat yang hidup di persilangan budaya atara Timur - Asia dan Barat - Eropa.

Identitas naratif adalah kisah diri yang terinternalisasi dan dikembangkan yang dibangun oleh seseorang untuk memahami makna kehidupan (McAdams, 2011). Melalui identitas naratif ini, seorang pembaca bisa merekonstruksi kembali makna diri penulis melalui karya autobiografinya. Pembaca perlu melakukan pengecekanpengecekan dan mengevaluasi pikiranpikiran, peristiwa-peristiwa di dalam roman untuk kemudian dibawa keluar, didialogkan dan dihubungkan dengan pengamalan-pengalaman-pengalaman dan emosi-emosinya agar terjadi transaksi kebermakaan karya sastra bagi dirinya.

Identitas naratif berkaitan dengan 'diri' seseorang. Oyserman et all (2012) berpendapat bahwa 'diri' dan 'konsep diri' (oleh Erikson disebut identitas) merupakan konstruksi dinamis yang didasarkan pada motivasi, perubahan/ dinamis, dan tindakan. Konsep diri bersifat dinamis dan dapat berubah, didasarkan pada hal-hal yang ada di dalam dirinya, termasuk motivasi yang mengarahkan seseorang untuk melakukan suatu tindakan tertentu. Secara umum, konsep diri merupakan persepsi diri individu tentang perilaku, kemampuan, dan karakteristik unik yang dimilikinya atau gambaran mental tentang diri sebagai pribadi (Bailey dikutip melalui Cherry, 2020). Konsep diri atau self-concept seseorang dibagi menjadi tiga, yaitu (1) gambaran diri atau self-image, (2) harga diri atau self-esteem, dan (3) harapan diri atau self-ideal (Rogers dikutip melalui Mishra, 2016; Cherry, 2020)

Penelitian lain tentang bagaimana seseorang mengalami permasalahan tentang identitas dirinya dilakukan oleh Harjani (2010) berjudul Japanese American's Self-Identity Problem in Monica Sone's Nisei Daughter, yang diterbitkan di jurnal Litera pada tahun 2010. Hasil kajiannya menunjukkan bahwa kelompok Nisei mengalami masalah identitas diri yang diakibatkan oleh kebingungan terhadap posisi kultural dan hukum mereka di Amerika. Masalah tersebut timbul karena faktor internal yang berasal dari masyarakat Amerika keturunan Jepang, yaitu kuatnya budaya Jepang, sehingga mereka berada dalam 
dua budaya (Amerika dan Jepang), dan faktor eksternal, yaitu rasisme kulit putih, yang menolak mereka sebagai bagian dari kelompok kulit putih meskipun kelompok Nisei adalah warga negara Amerika.

Selain itu, penelitian lain dilakukan oleh Iswalono dan Anggraeni (2018). Penelitian ini mengkaji puisi-puisi sastrawan imigran anglo-saxon, yang diterbitkan dalam jurnal Litera berjudul Diaspora Etnik Non-Anglo-Saxon dalam Masyarakat Etnik Anglo Saxon: Kegetiran Dan Keterasingan. Hasil penelitian menunjukkan bahwa represi yang dialami oleh etnik minoritas sebagaimana direpresentasikan oleh persona dalam puisi (Bilingual Sestina karya Julia Alvarez, Blood karya Naomi Shihab Nye, Bilingual/Bilingile karya Rhina P. Espaillat, dan To My Sister Lê Thi Diem Trinh Shrapnel Shards On Blue Water karya Lê Thi Diễm Thúy) terjadi dalam aspek kehidupan sosial-budaya, ekonomi, dan politik mereka. Represi tersebut tidak hanya dilakukan oleh etnik mayoritas Anglo-Amerika, namun juga oleh kelompok mereka sendiri. Resistensi yang mereka lakukan pun terjadi dalam bidang yang sama. Jati diri yang mereka temukan berpijak pada resistensi yang mereka lakukan yang sebetulnya merupakan "counter attack" mereka.

Pencarian identitas diri merupakan upaya untuk meneguhkan suatu konsep diri yang bermakna, merangkum semua pengalaman berharga di masa lalu, realitas keyakinan yang terjadi termasuk aktivitas yang dilakukan sekarang serta harapan di masa yang akan datang menjadi sebuah gambaran tentang 'diri' yang utuh, berkesinambungan dan unik.
Identitas diri seseorang adalah suatu kondisi psikologis secara keseluruhan yang membuat individu menerima dirinya, memiliki orientasi dan tujuan dalam mengarahkan hidup serta keyakinan internal.

\section{METODE}

Penelitian ini menggunakan metode penelitian deskriptif kualitatif dengan menggunakan teknik analisis interpretatif/ reflektif. Kata-kata, frase, kalimat serta tindakan-tindakan dalam roman Stupeur et Tremblements karya Amélie Nothomb digunakan sebagai sumber data primer untuk mengungkapkan dan menjelaskan tentang identitas diri perempuan Barat Belgia, Eropa yang berada di TimurJepang Jadi, kata-kata yang menunjukkan identitas diri tokoh utama dalam roman ini merupakan objek kajian dalam penelitian ini.

Pengumpulan data dilakukan dengan teknik membaca, mencatat, mengklasifikasikan, dan mengkoding. Data yang terkumpul kemudian dikategorisasi, dianalisis, diinterpretasikan dan direfleksikan untuk kemudian disajikan sebagai hasil penelitian. Instrumen yang dipergunakan untuk mengumpulkan data dalam penelitian ini berupa tabel data yang digunakan untuk menyusun tema-tema emergen yang sering muncul. Tabel data ini digunakan guna mempermudah pencatatan sejumlah data dan juga guna mempermudah pengkategorian data.

Teknik analisis data penelitian ini menggunakan teknik analisis data kualitatif dengan langkah-langkah yaitu (1) membaca berkali-kali data yang terkumpul, (2) membuat catatan-catatan awal, (3) menentukan tema emergen / 
yang muncul dari data yang terkumpul melalui tabel data, (4) merumuskan tema superordinat, (5) menata seluruh tema, (6) melaporkan hasil analisis.

Validitas dan reliabilitas data penelitian dipergunakan teknik validitas semantis dan teknik intrarater dan interrater. Validitas semantis yaitu dengan menganalisis konteks pemaknaan terhadap teks atau naskah. Sementara untuk reliabilitas data dipergunakan teknik intrarater yaitu dengan cara membaca berulang-ulang sehingga diperoleh kekonsistenan data dan teknik interrater yaitu berupa diskusi dengan teman sejawat dan juga dosen pembimbing senior.

\section{HASIL DAN PEMBAHASAN Hasil}

Berdasarkan penelitian yang telah dilakukan, berikut ini disampaikan konsep diri tokoh perempuan dalam autobiografi Amélie Nothomb berjudul Stupeur et Tremblements (1999) yang meliputi (1) gambaran/citra diri atau selfimage, (2) harga diri atau self esteem, (3) harapan diri atau self-ideal.

Gambaran diri atau self-image tokoh "Je" atau "Saya" sebagai tokoh Amélie sekaligus narator dan penulis disajikan pada Tabel 1.

\section{Tabel 1. Gambaran/Citra dalam Stupeur et Tremblements Karya Amélie Nothomb}

\begin{tabular}{ccl}
\hline No & \multicolumn{1}{c}{ Karakteristik } & \multicolumn{1}{c}{ Gambaran/Citra Diri Tokoh Amélie } \\
\hline 1 & Karakteristik Fisik & Berkulit putih/blanche \\
& Berumur 22 tahun. \\
Personal traits/sifat-sifat & Percaya Diri, Berani, aktif dan gesit \\
& & Talkative/Komunikatif, Terbuka/apa adanya, Mudah bergaul/ \\
& Fleksibel \\
& Menyukai tantangan/petualangan atau hal yang baru \\
& Imaginatif, Kreatif, Melankolik, dan Inisiatif \\
& Rasional/Logis, Pragmatis \\
& Cerdas, Terdidik dan menguasai Bahasa Jepang, Bahasa Prancis \\
& dan Inggris \\
& Individualis \\
& Bertanggung jawab dan Pekerja keras dan gigih \\
& Percaya pada Tuhan. \\
& Warga Negara Belgia (Wilayah Wallonia yang berbahasa \\
& Prancis). \\
& Karyawan kontrak di Yumimoto, Jepang sebagai penerjemah \\
& (Mulai bekerja di perusahaan Yumimoto pada Januari 1990 - \\
& 1991). \\
& Berperan sebagai suruhan Nona Mori Fubuki yang merupakan \\
& bawahan Tuan Saito, Tuan Omochi, dan Tuan Haneda. \\
& Juru ketik, pembuat teh, tukang foto kopi, juru salin angka dan \\
data di bagian keuangan, tukang bersih-bersih toilet. \\
Lajang.
\end{tabular}

Kosep Diri Perempuan di Persimpangan Budaya dalam Autobiografi Stupeur Et... 
Harga diri atau self-esteem menurut para humanis (Rogers dan Maslow) selalu dikaitkan dengan kebutuhan sesorang untuk mengaktualisasikan dirinya. Peringkat kebutuhan kebutuhan tokoh "Je" atau "Saya" sebagai tokoh
Amélie sekaligus narator dan penulis Stupeur et Tremblements disajikan pada Tabel 2.

Selanjutnya, self ideal atau harapan diri Amélie dalam roman Stupeur et Tremblements disajikan pada Tabel 3.

Tabel 2 Peringkat Kebutuhan dalam Stupeur et Tremblements Karya Amélie Nothomb

\begin{tabular}{|c|c|c|c|}
\hline $\begin{array}{l}\text { Peringkat } \\
\text { Kebutuhan }\end{array}$ & $\begin{array}{l}\text { Aspek } \\
\text { Kebutuhan } \\
\text { Manusia }\end{array}$ & Harga Diri / Self-esteem tokoh Amélie & Keterangan \\
\hline 1 & $\begin{array}{l}\text { Aktualisasi } \\
\text { Diri }\end{array}$ & $\begin{array}{l}\text { Menjadi penerjemah profesional Bahasa } \\
\text { Jepang/Prancis. } \\
\text { Kembali ke Belgia dan menjadi penulis sukses. }\end{array}$ & $\begin{array}{l}\text { Tidak terpenuhi } \\
\text { Terpenuhi }\end{array}$ \\
\hline 2 & Penghargaan & $\begin{array}{l}\text { Status pekerjaannya tidak jelas, tidak } \\
\text { mendapat penghargaan. } \\
\text { Mendapat perlakuan yang tidak seharusnya }\end{array}$ & Tidak terpenuhi \\
\hline 3 & Sosial & $\begin{array}{l}\text { Teralienasi secara sosial, berbeda secara } \\
\text { budaya } \\
\text { Tertolak secara sosial, tidak diterima secara } \\
\text { sosial } \\
\text { Hubungan dengan pimpinan-pimpinannya } \\
\text { tidak harmonis }\end{array}$ & Tidak terpenuhi \\
\hline 4 & Rasa Aman & Tidak ada rasa aman, selalu takut dan gemetar & Tidak terpenuhi \\
\hline 5 & Fisiologis & $\begin{array}{l}\text { Terpenuhi dengan mendapat gaji yang layak, } \\
\text { mendapat tempat / meja untuk bekerja, makan } \\
\text { \& minum terpenuhi. }\end{array}$ & Terpenuhi \\
\hline
\end{tabular}

Tabel 3Self Ideal atau Harapan Diri Tokoh Amélie

\begin{tabular}{ll}
\hline \multicolumn{1}{c}{ Harapan diri } & \multicolumn{1}{c}{ Kenyataan / Discrepancy } \\
\hline Pencarian identitas diri sebagai seorang yang & Penolakan/Tidak disukai/Tidak dicintai \\
pernah dilahirkan dan tumbuh sampai usia 5 th & Direndahkan/Diremehkan \\
di Jepang, ingin menjadi seorang Jepang. & Dianggap tidak ada \\
Menjadi Penerjemah Jepang-Belgia/Prancis & $\begin{array}{l}\text { Tidak dipercaya dan tidak diberi tugas sebagai } \\
\text { penerjemah }\end{array}$ \\
\hline
\end{tabular}




\section{Pembahasan}

Konsep diri atau self-concept seseorang dibagi menjadi tiga, yaitu (1) gambaran diri atau self-image, (2) harga diri atau selfesteem, dan (3) harapan diri atau self-ideal (Rogers dikutip melalui Mishra, 2016; Cherry, 2020).

\section{Gambaran Diri atau Self-Image}

Gambaran diri yang paling mudah dikenali adalah nama. Dalam roman Stupeur et Tremblements karya Amélie Nothomb (1999) tokoh utamanya berperan sekaligus sebagai narrator/ pencerita dan penulis. Tokoh "Je" dalam bahasa Prancis merupakan sebutan untuk orang pertama tunggal yang berarti 'saya' atau 'aku'. Penelitian Cowley (2011) terhadap roman ini telah membuktikan bahwa roman ini memang merupakan genuin roman autobiografi yang tidak dapat dipisahkan dengan Amélie Nothomb sebagai penulisnya.

Tokoh "Je" atau "saya/aku", muncul di setiap halaman, merepresentasikan seseorang wanita bernama Amélie. Ada kurang lebih sepuluh kali penyebutan nama diri "Amélie" oleh tokoh-tokoh lain dalam roman ini, antara lain oleh Tuan Haneda sebagai Presiden/Direktur Yumimoto, "Vous êtes sûrement Améliesan!" (hal 85) - "Anda pasti Nona Amélie!" (Nothomb, 1999: 85); oleh Tuan Tensi ketika berhadapan dengan Tuan Omochi, Wakil Direktur Yumimoto, "Il aurait rencontré beaucoup plus d'obstacle qu'Amelié-san!," (hal 45) -"Dia (Mr. Saitama) akan mengalami banyak kesulitan dibandingkan Nona Amélie!" (Nothomb, 1999: 45); tokoh Tuan Omochi dan Tuan Saito yang menyebut namanya ketika Amélie hendak berpamitan mengundurkan diri setelah satu tahun menyelesaikan kontraknya, "Amélie-san!” (hal 163, 169). Selain itu, oleh satu-satunya tokoh perempuan Jepang dalam roman ini, yaitu Nona Fubuki Mori, mantan atasan langsung, nama Amélie disebut pada surat ucapan selamat yang ditujukan kepadanya yang berhasil menerbitkan roman pertama berjudul Hygene de l'Assassin pada tahun 1993 (3 tahun setelah keluar dari Yumimoto). Surat pendek berbahasa Jepang itu berbunyi, "Amélie-san, Félicitation. Mori Fubuki." (hal 175) - "Nona Amélie, Selamat. Mori Fubuki." (hal 175).

Nama Amélie berdasarkan Atlas Étymologique et Polyglotte des Noms Propres les plus Répandus, berasal dari bahasa Latin dan Yunani, yaitu Amelia yang mengacu pada nama feminin dan berarti seseorang yang sangat hati-hati (Bourdonné, 1962). Pengalaman-pengalaman yang diperoleh selama satu tahun (1990-1991) di Yumimoto, Jepang, oleh Nothomb diendapkan, dicerna, dan direfleksikan, serta dituliskan melalui roman Stupeur et Tremblements selama delapan tahun, yaitu 1999. Sewindu lamanya Nothomb 'mengendapkan' dan mengekspresikan pengalaman-pengalaman getir selama menjadi imigran di Jepang dengan nada humor, menertawakan dirinya sendiri seperti tampak pada paragraf pertama roman ini.

"Monsieur Haneda était le supérieur de monsieur Omochi, qui était le supérieur de monsieur Saito, qui était le supérieur de mademoiselle Mori, qui était ma supérieure. Et moi, je n'etais la supérieure de personne. 
On pourrait dire les choses autrement. J'étais aux ordres de mademoiselle Mori, qui était aux ordres de monsieur Saito, et ainsi de suite, avec cette précision que les ordres pouvaient, en aval, sauter les échelons hiérarchiques. Donc, dans la companie Yumimoto, j'étais aux ordres de tout le monde." (hal 7)

"Tuan Haneda adalah atasan Tuan Omochi, yang merupakan atasan Tuan Saito, yang merupakan atasan Nona Mori, yang merupakan atasanku. Dan aku, bukan atasan siapapun. Kita dapat juga mengatakan dengan cara berbeda. Saya berada di bawah perintah Nona Mori, yang berada di bawah perintah Tuan Saito, dan seterusnya, dengan tepat tentu saja perintah-perintah itu dapat melompat ke tangga hierarkis. Jadi, di perusahaan Yumimoto aku adalah suruhan dari semua orang." (hal 7).

Melalui kutipan di atas pembaca dapat memahami beberapa hal. Pertama, setting cerita dalam roman Stupeur et Tremblemebents (1999) adalah budaya Jepang dengan penyembutan namanama tokoh Tuan Haneda, Tuan Omichi, Tuan Saito, Nona Mori dan penyebutan nama perusahaan Yumimoto. Kedua, peran sosial tokoh 'Je' atau Amélie sebagai seorang pegawai rendahan, menjadi pesuruh. Ketiga hubungan hirarkis antartokoh dalam roman terlihat sangat tertutup. Secara terperinci, hubungan antartokoh dapat divisualisasi sebagaimana terlihat pada Gambar 1 sebagai berikut:

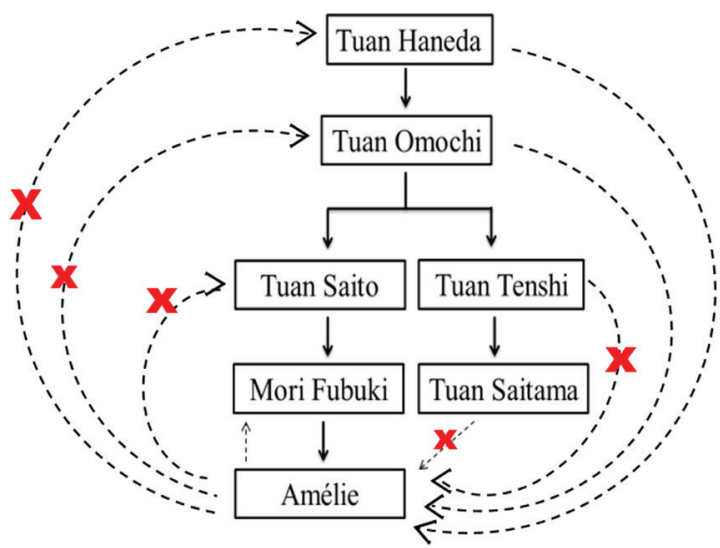

Gambar 1. Hubungan Hirarkis Tokoh Roman Stupeur et Tremblements

Nama-nama tipikal Jepang dalam roman Stupeur et Tremblements (1999) selalu disebut dengan menyertakan "Monsieur" dalam bahasa Inggris berarti 'Sir' atau 'Tuan' untuk tokoh laki-laki dan juga "Mademoiselle" yang berarti "Nona" untuk menyebut tokoh perempuan Jepang bernama Nona Mori Fubuki. Hal tersebut merepresentasikan konteks sosial dan budaya di lingkungan kerja di Jepang yang formal, hirarkis dan kaku. Tokoh-tokoh yang disebutnya sebagai Tuan dan Nona seperti dalam kutipan di atas merupakan tokoh-tokoh berkuasa dan memiliki superioritas terhadap diri si 'Aku' pencerita sekaligus narator dan tokoh utama. Tokoh utama memiliki posisi sosial yang paling rendah karena sebagai bawahan dan suruhan siapa saja di kantor Yumimoto, Jepang. Tokoh si 'Aku' adalah tokoh yang termarginalkan oleh sistem hirarkis di Jepang. Meskipun namanya disebut sebagai Amélie-san (sebagai tanda penghormatan), tetapi kenyataannya dia 
diperlakukan tidak manusiawi sebagai pembersih toilet lantai 44 Yumimoto atas nama senioritas, kepatuhan, dan kebiasaan yang telah menjadi budaya.

Tokoh Amélie mencoba untuk patuh terhadap pimpinan-pimpinannya, meskipun perintah-perintah mereka tidak masuk akal (bagi otak Barat), termasuk melupakan bahasa Jepang yang telah dengan fasih dikuasainya, seperti terlihat dalam kutipan dialog antara Tuan Saito dengan Amélie berikut.

-"Le cerveau nippon et probablement capable de se forcer a oublier une langue. Le cerveau occidental n'en a pas les moyens. Cet argument extravagant parut recevable a monsieur Saito.

-Essayez quand meme. Au moins, faites semblant. J'ai recu des ordres a votre sujet. Est-ce que c'est etendu?" Le ton etait sec et cassant." (Nothomb, 1999:20-21)

-"Otak Jepang mungkin bisa memaksakan diri untuk melupakan suatu bahasa. Otak Barat tidak melakukannya. Argumen yang luar biasa ini sepertinya diterima oleh Tuan Saito.

-Cobalah. Setidaknya pura-pura. Saya sudah sampaikan pesan untuk Anda tentang hal ini. Apakah jelas? Nada suaranya kering dan rapuh." (Nothomb, 1999:20-21).

Ciri-ciri dan karakteristik seseorang juga menunjukkan gambaran diri seseorang. Amélie seorang yang masih muda, berumur 22 tahun, berambut pirang dan berkulit putih, dengan ukuran tubuh kira-kira $165 \mathrm{~cm}$, warga negara Belgia dan belum menikah. Dalam roman Stupeur et Tremblement digambarkan sebagai seorang yang ekspresif, terbuka, suka bicara apa adanya. Dengan mudah dia bercerita kepada atasannya, Mori Fubuki, tentang perasaan kekesalannya terhadap Tuan Saito yang notabene adalah atasan mereka berdua, "Je hais monsieur Saito. C'est un salaud et un imbécile."- "Aku benci Tuan Saito. Dia seorang haram jadah/ bajingan dan seorang idiot." (hal 23). Kutipan tersebut menunjukkan bahwa tokoh Amélie lupa dan spontan bercerita kepada atasannya langsung, seorang wanita Jepang (Nona Fubuki) yang begitu menghormati pimpinannya (Tuan Saito). Seorang bawahan di Jepang tidak mungkin membicarakan pimpinannya dengan demikian kasar dan tidak sopan.

Pemimpin atau atasan adalah seorang yang harus dihormati termasuk keputusan-keputusanya. Dalam hal promosi kenaikan jabatan tertentu biasanya di perusahaan Jepang didasarkan pada senioritas dan sering kali umur menjadi tolok ukur jabatan (Japan Intercultural Consulting, 2020). Pemahaman terhadap budaya hirarki di perusahaan Jepang sangat penting karena kesalahan bersikap atau bertutur kata akan fatal akibatnya. Seorang karyawan dapat dianggap kurang ajar dan tidak berbudaya jika membantah atau menyatakan ketidaksetujuannya secara langsung kepada atasannya. Bawahan tidak punya hak untuk menjawab atau membantah seperti diungkap oleh Nothomb, "Il était clair que je n'avais pas le 
droit de répondre par la négative." - "Jelas bahwa saya tidak punya hak untuk mengatakan tidak." (hal 9). Berkali-kali Amélie mencoba untuk berdialog, tetapi justru dianggap tidak sopan, "Taisez-vous! De quel droit vous défendez-vous?"- "Diam Anda! Atas dasar hak apa Anda melawan?" (hal 19). Ketidaksetujuan secara langsung kepada atasan akan mengakibatkan seorang pemimpin kehilangan muka karena malu dan merasa tidak dihormati.

Dalam dunia bisnis di Jepang (Japan Intercultural Consulting, 2020), Jepang dan non-Jepang memiliki ide yang sangat berbeda tentang bagaimana mengekspresikan perbedaan pendapat dalam percakapan. Di sebagian besar budaya Barat, perbedaan pendapat dalam suatu diskusi adalah hal wajar. Debat adalah keterampilan yang diasah di sekolah dan juga di luar sekolah sepanjang hidup, dan bahkan mungkin dianggap sebagai hobi yang menyenangkan. Sementara dalam budaya Jepang, sebaliknya, percakapan cenderung tentang mencari area kesamaan, harmonisasi. Ekspresi pendapat yang bertentangan harus dihindari. Jika terpaksa harus bertentangan maka hal tersebut harus dilakukan secara cermat dan hati-hati. Keterusterangan tentang ketidaksukaan seseorang terhadap ide orang lain, apalagi pimpinan dianggap sebagai suatu tindakan yang tidak sopan dan menciptakan suasana gaduh serta tidak harmonis. Hal inilah yang dialami oleh Amélie dalam Stupeur et Tremblements (1999). Amélie selalu berusaha untuk berdiskusi atau berdebat kepada atasannya. Alih-alih mendapat promosi jabatan di Yumimoto, karirnya justru merosot secara drastis. Amélie mendapat kontrak sebagai penerjemah, secara berangsur-angsur dia bekerja sebagai juru ketik (hal 9) dan pembuat minuman teh untuk kolegakoleganya pada bulan pertama (hal 16), juru foto kopi pada akhir bulan kedua (hal 31-40), penyalin angka-angka di bagian keuangan pada bulan kelima (hal 54), dan terakhir sebagai pembersih toilet (pria dan wanita) di lantai 44 perusahaan Yumimoto pada bulan ketujuh sampai bulan kedua belas (hal 124-155).

Hirarki sangat penting dalam budaya perusahaan Jepang. Status seseorang dalam suatu organisasi menentukan bagaimana anggota berinteraksi satu sama lain dan bagaimana mereka mengharapkan orang lain berinteraksi dengan mereka (Japan Intercultural Consulting, 2020). Senioritas dalam dunia bisnis maupun organisasi sosial di Jepang adalah hal yang sangat penting dan harus ditaati oleh anggotanya, termasuk Amélie tidak bisa melompat dan mendapat jabatan tanpa mengikuti prosedur yang telah ada. Amélie tidak bisa melompati Nona Mori Fubuki sebagai atasan langsungnya dan mendapat jabatan dari Tuan Tensi (atasan tidak langsung) meskipun pekerjaan tersebut dikerjakannya dengan sangat bagus. Kutipan dialog antara Mori Fubuki dan Amélie berikut memberikan gambaran tentang hal tersebut:

"- J'ai vingt-neuf ans, vous en avez vingtdeux. J'occupe mon poste depuis l'an passé. Je me suis battue pendant des années pour l'avoir. Et vous, vous imaginiez que vous alliez obtenir un grade équivalent en quelques semaines?

- C'est donc ça! Vous avez besoin que je souffre. Vous ne supportez pas la chance des 
autres. C'est puéril!

Elle eut un petit rire méprisant:

- Et aggraver votre cas comme vous le faites, vous trouvez que c'est une preuve de maturité? Je suis votre supé-rieure. Croyezvous avoir le droit de me parler avec cette grossièreté?

- Vous êtes ma supérieure, oui. Je n'ai aucun droit, je sais. Mais je voulais que vous sachiez combien je suis déçue. Je vous tenais en si haute estime.

Elle eut un rire élégant:

- Moi, je ne suis pas déçue. Je n'avais pas d'estime pour vous." (Nothomb, 1999: 53).

-" Saya berumur dua puluh sembilan, Anda dua puluh dua. Saya berada di posisi saya sejak tahun lalu. Saya berjuang selama bertahun-tahun untuk mendapatkannya. Dan Anda, apakah Anda membayangkan bahwa Anda akan memperoleh posisi yang setara dalam beberapa minggu?

- Jadi begitu! Anda menginginkan saya menderita. Anda tidak tahan dengan keberuntungan orang lain. Ini kekanakkanakan!

Dia tertawa menghina:

- Dan membuat kasus Anda lebih buruk seperti yang Anda lakukan, apakah Anda pikir itu bukti kedewasaan? Aku atasanmu Apakah Anda pikir Anda memiliki hak untuk berbicara kepada saya dengan kekasaran seperti itu?

- Anda adalah atasan saya, ya. Saya tidak punya hak, saya tahu. Tapi aku ingin kau tahu betapa kecewanya aku. Aku begitu menghargai Anda.

Dia tersenyum dengan elegan dan berkata:

-Saya tidak menyesal. Saya tidak menghargai Anda." (Nothomb, 1999:53).

Kesalahanpahaman budaya muncul dalam bersikap dan bertindak sejak Amélie menginjakkan kakinya pertama kali di perusahaan Yumimoto pada tanggal 8 Januari 1990 dengan tanpa melaporkan kehadirannya di front office Perusahaan Yumimoto dan justru langsung menuju ke lantai 44 perusahaan tersebut. Hal ini membuat Tuan Saito, atasannya tidak senang. Tindakan Amélie dianggap tidak prosedural. Padahal, prosedur dan hirarkis demikian penting dalam budaya perusahaan di Jepang (Japan Intercultural Consulting, 2020). Salah bertindak akan berakibat fatal karena dia akan dianggap sebagai seorang yang tidak tahu aturan. Prosedur itu juga harus diikuti oleh karyawan ketika ingin berbicara tentang pekerjaan, seorang karyawan hanya boleh berbicara kepada atasannya langsung, tidak bisa melompati tingkatan hirarkis di atasnya. Seperi diungkap oleh Amélie, "Je n'avais le droit de m'adresser qu'à mon supérieur direct, qui se trouvait être mademoiselle Mori."-"Aku hanya punya hak untuk berbicara kepada atasanku langsung, yaitu Nona Mori." (hal 24).

Amélie adalah seorang yang pragmatis. Tindakan pragmatisnya untuk membantu Tuan Tensi (departemen lain) dalam menyelesaikan laporannya tentang konsumsi susu dan produk-produk susu lainnya di Belgia untuk Yumimoto, dianggap salah oleh Wakil Direktur, Tuan Omichi. Tindakan pragmatis tersebut dianggap melangkahi atasannya langsung yaitu Mori Fubuki dan menyerobot pekerjaan orang lain. 
Menyerobot pekerjaan orang lain artinya mementingkan diri sendiri dan individualistis. Dalam kaca mata budaya Jepang sikap individualisits tidak bisa diterima karena hal tersebut bertolak belakang dengan nilai kebersamaan dalam keharmonisan.

Amélie juga seorang pemikir dan imajinatif. Gambaran diri tokoh Amélie sebagai pemikir tampak melalui kutipan, "J'avais trouvé ma vocation. Mon esprit s'epanuissait dans ce travail simple, utile, humain, et propice à contemplation." "Seharusnya aku menemukan panggilan hidupku. Waktu itu, jiwaku tak sadarkan diri dalam pekerjaan yang sederhana, penting, manusiawi dan kontemplatif." (ha1 28). Kalimat "J'avais trouvéma vocation," bahasa Prancis disebut kalimat conditionnel passé / atau dalam bahasa Inggris disebut past conditional untuk mengekspresikan suatu keinginan yang tidak terjadi pada waktu lampau. Melalui kutipan di atas, tampak bahwa sebetulnya sejak awal tokoh Amélie tidak menikmati pekerjaan yang seharusnya bukan bagiannya. Meskipun demikian dia mencoba untuk bertahan mencoba untuk menyelami cara pikir Jepang.

"Présenter ma démission eut été le plus logique. Pourtant, je ne pouvais me résoudre a cette idée. Aux yeux d'un occidental, ce n'eut rien eu d'infamant; aux yeux d'un japonais, c'eut été prendre la face, j'étais dans la compagnie depuis un mois a peine. or, j'avais signe un contrat d'un an. Partir après si peu de temps m'eut couverte d'opprobre, a leurs yeux comme aux miens."(Nothomb, 1999:21)
"Menyerahkan pengunduran diri saya akan menjadi hal yang paling logis. Namun, saya tidak bisa membawa diri saya ke ide ini. Di mata orang Barat, itu tidak memalukan; Di mata orang Jepang, akan hilang muka, saya berada di perusahaan selama sebulan. Saya menandatangani kontrak satu tahun. Pergi dalam waktu yang begitu singkat adalah aib seperti juga begitupun pandanganku (Nothomb, 1999: 21)

Usahanya untuk bertahan dan mencoba 'menikmati' setiap pekerjaan yang diberikan untuknya (meskipun bukan sebagai penerjemah) dan menyelesaikan kontraknya selama satu tahun (meskipun baginya serasa sepuluh tahun ) menunjukkan bahwa Amélie adalah seorang bertanggung jawab. Semangat tokoh Amélie untuk menjadi seorang Jepang yang mengalami kegagalan, menunjukkan bahwa akulturasi budaya itu bukanlah suatu yang mudah dan tidak bisa dilakukan dalam waktu singkat. Lahir dan hidup lima tahun di masa kecil di Jepang tidak menjamin Amélie untuk dapat di terima kembali di masyarakat Jepang yang sudah tujuh belas tahun ditinggalkannya. Bagaimanapun juga, bagi tokoh-tokoh superior Yumimoto, Amélie tetaplah seorang imigran, orang luar, orang asing yang tidak memahami budaya Jepang.

Harapan untuk merasakan kebahagiaan berada di Jepang merupakan hiburan yang membebaskannya dari segala hal di luar nalarnya, "me jeter dans la vue" - melemparkan pandangannya jauh melewati jendela kaca di salah satu ujung lorong perusahaan Yumimoto di 
ketinggian merupakan 'obat' kerinduannya terhadap tanah yang pernah memberinya kehidupan. "Loin, très loin, il $y$ avait la ville - si loin que je doutais d'y avoir jamais mis les pieds." - "Jauh, sangat jauh di sana, suatu desa - yang jauh yang aku ragu tak pernah meinginjakkan kakiku" (hal 8).

Amélie secara rutin dan hampir tiap hari menikmati pemandangan 'jendela kaca besar' di ujung lorong untuk melakukan perjalanan secara 'imajinatif', suatu perjalanan spiritual yang membebaskannya dari pekerjaan remehtemeh (tidak memerlukan pikiran) yang setiap hari selama satu tahun harus dikerjakannya demi untuk menjadi seorang Jepang, terbebas dari rasa malu. Pengalaman getir dan penolakanpenolakan yang dirasakan Amélie selama satu tahun berada di Yumimoto merupakan masa kontemplatif yang memberinya banyak pengalaman dan juga memunculkan kesadaran terhadap dirinya sendiri. Kesadaran diri bahwa dirinya bukanlah seorang Jepang dan tidak pernah akan bisa menjadi Jepang, apapun dan bagaimanapun caranya. Tempatnya bukan di Jepang tetapi di Eropa.

Sebagai seorang Belgia, tokoh Amélie adalah pemberani, aktif, dan gesit. Keberaniannya ditunjukkan dengan melakukan perjalanan, melintasi ruang dan waktu dari benua Eropa, Belgia (Brussel) menuju benua Asia, Jepang (Tokyo) dengan jarak $9.388 \mathrm{~km}$ atau 5.833 miles. Perjalanan yang cukup panjang dan melelahkan meskipun ditempuh dengan pesawat, yaitu kurang lebih $14-18$ jam ditempuhnya dengan harapan menemukan jati dirinya sebagai seorang yang pernah lahir dan tumbuh di Jepang. Memori dan kenangan indah tentang 'rumah' atau 'home' yang pernah dirasakannya di masa kecil merupakan motivasi yang selalu dihadirkannya dalam benak dan pikirannya. Impian ini merupakan kekuatannya untuk bertahan dan menjalani kehidupannya satu tahun di Yumimoto yang terasa sepuluh tahun. Imaginasi dan ingatannya tentang masa kecilnya yang bahagia di Jepang, menjadi salah satu kekuatannya untuk bertahan, "...j'avais toujours éprouvé le désir de vivre dans ce pays auquel je vouais un culte depuis les premiers souvenirs idylliques que j'avais gardes de ma petite enfance." - "... Aku selalu menginginkan dan bersumpah untuk hidup di negara ini, dimana kenangan indah pertama tersimpan sejak masa kecilku." (hal 22). Dapat dikatakan bahwa Stupeur et Tremblements merupakan suatu roman perjalanan menelusuri kembali masa lalunya untuk pencarian identitas dirinya sebagai seorang yang pernah menjadi bagian Jepang dan memiliki kenangan indah serta menyenangkan di desa Shukugawa dekat gunung Kabuto, Jepang).

Dari gambaran diri tokoh Amélie di atas, dapat disimpulkan bahwa tokoh perempuan Belgia ini mengalami benturan budaya di Jepang. Amélie yang awalnya ingin melebur menjadi orang Jepang dan membayangan dirinya sebagai geisha yang berkulit putih - geisha blanche yang siap berkorban demi kebahagiaan orang lain, justru menjadi Yankee, yaitu perempuan yang dianggap urakan, tidak berguna, dan tidak tahu aturan serta tidak berbudaya. Jurang 
perbedaan pemikiran dan budaya Jepang

- Belgia yang demikian dalam, memaksanya untuk kembali ke Barat, Eropa. Di Belgia, Amélie justru dapat mengembangkan dan mengasah bakatnya menulis dan berpikir.

\section{Kebutuhan terhadap Harga Diri atau 'Self-Esteem'}

Inti dari munculnya harga diri adalah kebutuhan seseorang terhadap otonomi yang terus berkembang secara dimanis seiring berjalannya waktu. Dalam pandangan Rogers, harga diri / nilai diri atau self esteem atau self-worth selalu melibatkan tingkat evaluasi yang mungkin bisa positif atau negatif tentang diri sendiri, dan juga melibatkan bagaimana kita memikirkan tentang diri sendiri (Mishra, 2016: 9). Dalam konteks roman Stupeur et Tremblements karya Amélie Nothomb, sejak awal Amélie sudah memahami bahwa harga dirinya direndahkan oleh tokoh-tokoh superior di Yumimoto, tempatnya bekerja di Jepang.

Derajat sosial Amélie yang turun secara drastis berturut-turut selama satu tahun menunjukkan adanya benturan kebudayaan antara kebudayaan Timur, yaitu Jepang dengan budaya Barat, Belgia-Eropa. Amelie yang awalnya dikontrak sebagai sebagai penerjemah, harus menerima dirinya sebagai seorang adalah tukang ketik, juru salin informasi kepegawaian seluruh karyawan Yumimoto, kemudian pembuat teh / dame d'ôchakumi (Nothomb, 1999: 17), tukang foto kopi, pengumpul dan penyalin angka-angka di bagian keuangan, dan tujuh bulan terakhir menjadi pembersih toilet di lantai 44 .
Harapan dirinya berbeda dengan kenyataan yang dihapinya selama satu tahun bekerja di Yumimoto, Jepang.

Kesemua pekerjaan-pekerjaan tersebut dijalaninmya dengan sungguhsungguh meskipun selalu dianggap salah oleh atasan-atasannya, terutama tokoh Tuan Haneda, Tuan Omichi, Tuan Saito, Nona Mori. Tokoh si 'Aku' pencerita berusaha menenggelamkan diri dan melebur ke dalam budaya Jepang. Cowley (2011: 274) dalam penelitiannya menyebutkan bahwa tokoh 'Aku' yang awalnya berharap penuh untuk diterima sebagai penerjemah, mau melakukan apapun termasuk menghapus dirinya sendiri/self-effacing hingga sampai batas yang tidak dapat dipahami atau melakukan suatu kebodohan (borderline obtuse).

Menurut Rogers (1959), manusia secara fundamental memiliki suatu dorongan dalam sistem kepribadiaannya untukmemeliharadiri,mengaktualisasikan diri, meningkatkan dan mengembangkan diri (Schultz\&Schultz, 2009). Seseorang dapat berfungsi sepenuhnya dengan mengaktualisasikan dirinya secara terus menerus sehingga dapat berfungsi bagi masyarakat. Rogers (1959) memberikan lima sifat orang yang berfungsi secara sepenuhnya, yaitu (1) memiliki kesadaran terhadap pengalaman-pengalamannya; keterbukaan terhadap pengalaman dengan tidak menolak atau menghilangkannya/menutupi ataupun sikap defensif, (2) hidup secara eksistensial - hidup secara sepenuhnya dalam setiap momen, (3) percaya terhadap dirinya sendiri sebagai organisme, yaitu dengan bertingkah laku menurut apa yang dirasa benar, (4) memiliki perasaan bebas untuk memilih 
tanpa adanya paksaan-paksaan atau rintangan-rintangan, (5) dapat menghadapi permasalahan-permasalahan yang merupakan suatu tantangan atau tes untuk tumbuh, mengarahkan diri dengan menggunakan potensinya untuk kebermanfaatan dan keberadaannya (Schultz \& Schultz, 2009: 333-334).

Jika mengacu pada teori Rogers tersebut di atas, selama di Jepang, Amélie tidak dapat dikatakan sebagai seorang yang berfungsi secara sepenuhnya. Di Jepang, Amelie tidak pernah diberi kepercayaan untuk mengembangkan dirinya sebagai seorang yang berbakat di bidang bahasa. Meskipun mendapat pekerjaan sebagai penerjemah dan mendapat gaji sebagai penerjemah dari perusaan Yumimoto, Amélie tidak pernah diberi kepercayaan untuk bekerja sebagai penerjemah. Meskipun kebutuhan-kebutuhan mendasarnya seperti mendapat tempat tinggal yang layak dan dapat memenuhi kebutuhan mendasarnya, tetapi kebutuhan-kebutuhan lainnya tidak terpenuhi. Kehidupannya selama di Jepang dan bekerja di Yumimoto merupakan pengalaman yang menakutkan.
Kebutuhannya terhadap rasa aman dengan demikian juga tidak terpenuhi. Secara sosialpun, Amelie selalu teralienasi dan merasa sendiri dalam kerumunan orangorang Jepang di Yumimoto. Selama di Jepang, dia juga tidak pernah dihargai atas pekerjaannya. Dia selalu dianggap salah dalam melakukan pekerjaannya. Pemenuhan kebutuhan Amélie Nothomb melalui Stupeur et Tremblements (1999) berdasarkan bagan kebutuhan Maslow disajikan pada Gambar 2.

Amelie dapat menjadi seorang yang sepenuhnya ketika kembali ke Belgia yaitu tahun 1991. Amélie menuangkan kesadarannya terhadap pengalamanpengalamannya, menunjukkan keterbuakaannya terhadap peristiwayang menyakitkan dengan penolakan-penolakan yang dialaminya selama di Jepang melalui tulisan. Dengan tulisan dia menjadi sadar dan percaya diri terhadap keberadaannya, eksistensinya. Kembali ke Belgia dan menjadi penulis menunjukkan bahwa sebagai pribadi dia bebas untuk menuliskan apa yang dipikirkannya tanpa adanya rasa takut terhadap paksaan-paksaan dan juga

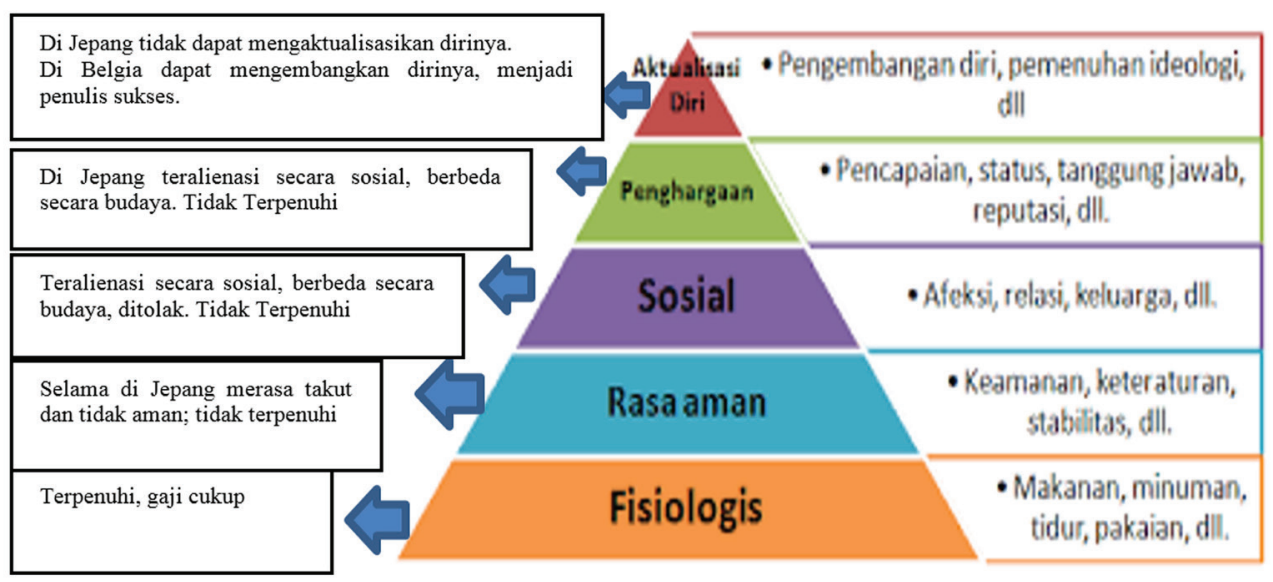

Gambar 2 Bagan Kebutuhan Self Esteem/Harga Diri Tokoh Améli menurut Maslow 
rintangan. Amelie dapat tumbuh dan semakin berkembang untuk mengarahkan dirinya dan mengoptimalkan potensinya untuk kebermanfaatan dan keberadaannya. Amelie dapat mengaktualisasikan dirinya dengan menjadi penulis.

\section{Harapan Diri yang berbeda dengan Kenyataan/Discrepansi}

Melalui Stupeur et Tremblements, Amélie menggambarkan kegagalannya menjadi seorang Jepang sejak pertama kali menginjakkan kaki di perusahaan Yumimoto tanpa melaporkan diri di resepsionis perusahaan. Kesalahan demi kesalahan dilakukannya tanpa disadarinya, misalnya menjawab perintah pimpinannya, membicarakan pimpinannya dengan bahasa yang tidak sopan, berargumen atau berdebat. Kesalahan karena dia berada pada tempat yang salah. Keberanian Amélie yang berkebangsaan Belgia, berbahasa Prancis (keturunan Walonia), terdidik dan menguasai bahasa Jepang (termasuk bahasa bisnis Tokyo yang terkenal sangat cepat berbicaranya) dianggap oleh tokoh lain, pimpinannya sebagai suatu ancaman dan mengganggu. Dia yang didik sebagai seorang Belgia, pemberani, harus belajar bahwa dalam budaya Jepang, pemberani dapat diartikan sebagai suatu yang tidak benar. Perbedaan inilah yang membuatnya terpaksa harus menjalani peran sosialnya sebagai pegawai terendah dan junior di Perusahaan Yumimoto, Jepang. Amélie harus berdamai dengan kegetiran dan tekanan batinnya selama satu tahun di Asia, Jepang.

Jika diperhatikan secara seksama, nama Amélie selalu disebut dengan imbuhan 'san.' Orang Jepang terkenal dengan kesopanan dalam bertutur kata, pengaturan protokol dan detail seluk beluk etiket berperilaku. Dalam Japan Intercultural Consulting (2020) disebutkan bahwa dalam dunia bisnis Jepang, secara etika orang biasanya memanggil satu sama lain dengan nama belakang kemudian ditambah akhiran '-san.' Di perusahaan yang lebih konservatif, orang sering disapa dengan gelar mereka daripada nama mereka, seperti bucho-san untuk kepala departemen. Jarang nama depan digunakan dalam bisnis di Jepang berbeda dengan orang non-Jepang terutama orang Barat, memanggil nama dengan nama belakang memberikan kesan kaku. Namun, bagi sebagian besar orang Jepang, dipanggil dengan nama depan adalah apa yang terasa tidak nyaman dan terlalu akrab. Sementara di perusahaan Jepang yang modern dan banyak berinteraksi dengan dunia internasional, terjadi hibridasi penyebutan. Kadang atau sering kali penyebutan nama telah mengadopsi cara non-Jepang dengan penggunaan nama depan seseorang atau bahkan nama panggilan saja dengan ditambah -san yang dapat digunakan pada nama laki-laki ataupun perempuan, bersifat unisex. Karena sifatnya unisex, maka 'san' dapat berarti 'Mr'- 'Tuan' atau 'Mrs''Ibu' atau 'Ms' -'Nona' yang merupakan suatu bentuk penyebutkan kehormatan dan pujian. Dalam konteks Amélie, panggilan penghormatan tersebut tidak dibarengi dengan sikap dan pemberian tugas yang sesuai dengan kemampuannya, sebagai penerjemah. Seperti yang telah diungkap pada bagian sebelumnya, Amélie yang berhadap dapat mengaktualisasikan dirinya sebagai seorang penerjemah terpaksa harus mengerjakan pekerjaanpekerjaan yang tidak membutuhkan 
kemampuannya tersebut. Secara berturutturut dia melakukan pekerjaan sebagai tukang ketik, juru salin informasi kepegawaian seluruh karyawan Yumimoto, kemudian pembuat teh/ dame d'ôchakumi, tukang foto kopi, pengumpul dan penyalin angka-angka di bagian keuangan (dan pembersih toilet di lantai 44 selama tujuh bulan terakhir. Harapan dirinya berbeda dengan kenyataan yang dihapinya selama satu tahun bekerja di Yumimoto, Jepang.

Pengalaman-pengalaman getir tersebut disampaikan oleh Amélie dengan humor dan mengandung satir atau ejekan seperti diungkap oleh Sylvester (2020) dan Soares (2012). Salah satu ungkapan satirnya, "Rien n'était plus normal, quand on débutait dans une compagnie nippone, que de commencer par l'ôchakumi - "la fonction de l'honorable thé". Je pris ce rôle d'autant plus au sérieux que c'était le seul qui m'était dévolu.". "Tidak ada yang lebih normal, di perusahan Jepang, selain memulai karir dengan menjadi penghantar teh atau ôchakumi - suatu tugas yang mulia sebagai penghantar teh yang terhormat. Aku mengambil peran ini dengan seserius mungkin karena hanya pekerjaan yang diberikan padaku."

Satir dalam karya sastra adalah cara berkomunikasi secara meta-bahasa untuk menyampaikan sindiran atau kritikan cerdas dengan humor dalam suatu cerita fiksi atau hal yang aneh atau absurd (Frye, 1971; Simpson, 2003). Melalui roman ini, Amélie menggunakan bahasa untuk mengungkapkan 'bahasa' hirarkis dan senioritas sebagai budaya di Jepang pada tahun 1990 dengan halus dan cerdas sekaligus lucu. Perempuan berpendidikan tinggi, berwawasan luas, dan mempunyai mahir berbahasa Jepang, Prancis dan Inggris, lolos tes kepegawaian yang ketat, namun tidak bisa mengembangkan dirinya di perusahaan Yumimoto, Jepang. Amélie harus mau mengikuti pola pikir dan budaya Jepang, memulai karir dari bawah. Dia dipaksa untuk tunduk mengikuti perintah atasannya tanpa syarat agar pimpinan-pimpinannya terhindar dari rasa malu. Konsep penceritaan yang ironis sering kali dikaitkan sebagai suatu mekanisme memproduksi suatu sindiran atau satir (Simpson, 2003).

Dalam roman Stupeur et Tremblements karya Amélie Nothomb ditunjukkan bahwa tokoh "je" berkeinginan tinggal di Jepang, negara yang dia impikan sejak kecil. Hal ini tampak pada penggalan novel yang berbunyi “...j'avais toujours éprouvé le désir de vivre dans ce pays auquel je vouais un culte depuis les premiers souvenirs idylliques que j'avais gardés de ma petite enfance " - "...aku selalu merasakan keinginan untuk hidup di negara ini (Jepang) yang telah aku begitu inginkan sejak kenangan indah pertama masa kecilku tersimpan." Tokoh "je" digambarkan memiliki keinginan untuk tetap tinggal di Jepang, negara yang didambakan sejak kecil. Namun, pada kenyataannya, cinta utopis yang selalu dihadirkan dan dirindukan sebagai kasih yang hangat dan meneduhkan, harus kandas di tengah jalan. Cintanya terhadap Jepang dan budayanya, harus kandas ditengah jalan. Cintanya terhadap tanah dimana dia dilahirkan, pertepuk sebelah tangan. Keinginan Amélie untuk melebur dan menjadi Jepang harus berhadapan dengan kenyataan bahwa 
tokoh Amélie ternyata tidak diperlukan, tidak diinginkan, dengan penolakanpenolakan halus dan penuh kesopanan à la Jepang.

Satir atau sindiran sering kali dilakukan seseorang dalam menghadapi keadaan yang membingungkan, tidak masuk akal atau ambigu. Ambiguitas perannya di Yumimoto, Jepang diungkapkan secara ironis seperti dalam kutipan, "Melalui roman ini, Amélie mencoba untuk berdamai dengan dirinya sendiri, "J'avais trouvé ma vocation. Mon esprit s'epanouissait dans ce travail simple, util, humain et propice à la contemplation. J'aurais aimé faire cela tout ma vie. "Aku pernah merasa seolah-olah telah menemukan panggilan hidupku. Jiwaku waktu itu pingsan dengan pekerjaan yang sederhana (tidak memerlukan pemikiran), bermanfaat, manusiawi, dan sangat kontemplatif. Dulu rasanya seolah-olah saya berharap dapat melakukannya seumur hidup". Keambiguitasan perannya di Yumimoto, ketidakjelasan deskripsi kerjanya, kecurigaan-kecurigaan yang dihadapinya, ketidakpercayaan atasannya dengan terhadapnya, ketiadaan teman selama bekerja di Yumimoto merupakan fakta yang harus dihadapi oleh Amélie. Kegamangan dan keambiguan sikap dan perilaku lingkungan sosial terhadapnya menjadikan Amélie terus mempertanyakan tentang keberadaan dirinya sebagai manusia, eksistensinya.

Pengalamannya menghadapi situasi yang ambigu seperti dalam kutipan di atas merupakan bagian latihan pribadi Amélie dalam mengembangkan dirinya dan pemikirannya menuju pendewasaan diri - menurut Piaget disebut sebagai postformal thought. Tahap postformal thought ditandai dengan pemikiran yang relativistik, mampu merespon suatu persitiwa dengan cara yang berbeda, tertantang dengan pandangan yang terpolarisasi, mampu berekonsiliasi, memilih tindakan-tindakan yang cocok menurut perspektifnya sendiri yang mungkin benar (Papalia, Olds, \& Feldman, 2001). Amélie mencoba beradaptasi dan 'menantang' dirinya sendiri untuk tidak bertindak seperti selayaknya orang Barat, tetapi dia mencoba berpikir dan bertindak seperti orang Timur. Amélie terus mencoba belajar untuk tunduk dan takluk mengikuti perintah atasannya di Yumimoto, meskipun hanya bertahan satu tahun $(1990$ - 1991). Di satu sisi memposisikan tokoh Amélie sebagai tokoh yang kurang beruntung, di sisi lain justru membuatnya menjadi perempuan yang kuat dan tangguh. Pengalamanpengalaman menyakitkan selama di Yumimoto merupakan 'bahan' tulisan romannya yang sangat 'kaya' yang 8 tahun kemudian dituangkan melalui karya-karyanya, salah satunya Stupeur et Tremblements hingga mendapat penghargaan Grand Prix, sebuah penghargaan prestisius di bidang sastra dari Académie Francaise pada tahun 1999. Penderitaannyaketika diperlakukan secara tidak manusiawi dan tidak dihargai, tidak dipercaya, dan tidak pernah diberi pekerjaan sebagai seorang penerjemah, dijadikan bahan untuk mengejek dirinya sendiri / self mockery.

Self-mockery atau menertawakan diri sendiri merupakan kemampuan kebahasaan tingkat tinggi. Seseorang yang dapat menertawakan dirinya sendiri 
adalah seseorang yang dapat menerima dirinya seperti apa adanya. Dia dapat mengolah pengalaman-pengalaman tersebut dengan menggunakan bahasa. Dalam pandangan Nothomb (Payot (2018) kelucuan yang ada dalam roman Stupeur et Tremblement yang diterbitkan tahun 1999 terletak pada jarak penceritaannya. Jarak antara peristiwa sesungguhnya yang dialaminya, yaitu pengalaman-pengalaman pahit bekerja di Yumimoto tahun 1990-1991 dan waktu mulai dituliskannya cerita, yaitu 1999. Sewindu (8 tahun) lamanya Amelie harus mengendapkan pengalamanpengalaman tersebut untuk menjadi sebuah cerita yang menarik, ironis dan lucu. Sebagaimana penelitian Corina da Rocha Soares (2012) menyebutkan bahwa Stupeur Et Tremblements karya Amélie Nothomb memberikan pemahaman tentang perspektif kehidupan dan realitas mental menuju keselamatan, optimisme, menggunakan humor dan ironi untuk pencerahan bagi dirinya. Pada akhirnya, Nothomb dapat 'merayakan' pengalaman getirnya di Jepang dengan tersenyum melalui karyanya yang diakui Accademie Francaise sebagai penerima penghargaan prestisius kesastraan Prancis 'Grand Prix' di tahun 1999. Selain itu, karya ini juga mendapat sambutan yang hangat oleh pembaca dengan diterjemahkan dalam 46 bahasa.

\section{SIMPULAN}

Autobiografi Amélie Nothomb dalam Stupeur et Tremblements menyuarakan permasalahan-permasalahan terkait konsep dan identitas dirinya sebagai seorang yang mengalami benturan kebudayaan. Identitas dirinya sebagai orang Barat (meskipun lahir dan tumbuh sampai usia lima tahun di Timur) tetap melekat dalam dirinya. Gegar budaya yang dialaminya merupakan hasil benturan budaya Barat dan Timur yang memang secara fitrah berbeda. Perbedaan budaya Barat dan Timur berkontribusi terhadap kebinguan dan proses asimilasi Amélie. Tokoh ini mengalami diskriminasi dan menghadapi prasangka buruk sebagai bentuk penolakan orang Timur terhadap orang Barat. Amélie, merepresentasikan orang Barat, menunjukkan pengalamannya bagaimana harga dirinya direndahkan di Timur. Kritikan halus atau satir yang diberikan oleh Amélie Nothomb dengan menertawakan dirinya sendiri melalui roman ini direnungkan agar tercipta hubungan timbal balik yang saling menguntungkan, saling melengkapi, dan saling memahami antara Barat dan Timur.

\section{UCAPAN TERIMA KASIH}

Artikel penelitian ini merupakan salah satu luaran penelitian mandiri yang dilakukan pada tahun 2019 berdasarkan skim mandiri Lembaga Penelitian dan Pengabdian Masyarakat Universitas Negeri Yogyakarta. Kepada pihak-pihak yang terlibat secara langsung ataupun tidak langsung dalam penelitian ini, peneliti mengucapkan terima kasih. Ucapan terima kasih juga disampaikan kepada kolega dan juga reviwer yang bersedia meluangkan waktunya untuk membaca dan mengoreksi dan memberi masukan terhadap perbaikan kualitas artikel penelitian ini. 


\section{DAFTAR PUSTAKA}

Cowley, P. (2011). Translation and translators in Amélie Nothomb's Autobiographical Fiction. Australian Journal of French Studies; Liverpool Vol. 48, Iss. 3, (Sep-Dec 2011):271-281. https://doi.org/ 10.3828/AJFS.48.3.271

Harjani, E. T. (2010). Japanese American's Self-Identity Problem in Monica Sone's Nisei Daughter. Litera Jurnal Penelitian Bahasa, Sastra, dan Pengajarannya, 9(2), 157-169. Retreived from https://journal.uny. ac.id/ index.php/litera/article/ view/1194/1006

Iswalono, S., \& Anggraeni, N. (2018). Diaspora Etnik Non-Anglo-Saxon dalam Masyarakat Etnik Anglo Saxon: Kegetiran dan Keterasingan. Litera Jurnal Penelitian Bahasa, Sastra, dan Pengajarannya, 17(3), 413-421. Retreived from https://journal.uny. ac.id/index.php/litera/issue/ view/1609.

Japan Intercultural Consulting. (2020). Japanese Business Etiquette Guide: Tanakasan or Tex? What to Call Japanese. Retreived February 17th, 2020. https:// www.japaninter cultural.com/en/ japaneseBusinessEtiquetteGuide / $\mathrm{T}$ a $\mathrm{n}$ a $\mathrm{k}$ a s a $\mathrm{n} \mathrm{O} \mathrm{r} \mathrm{T}$ e $\mathrm{x}$ WhatToCallJapanese.aspx

Lejeune, P. (1996). Le Pacte Autobiographie. Paris: Édition du Seuil.

Mishra, S.K. (2016). Self-concept-A Person's Concept of Self-Influence. International Jpurnal of Recent Research Aspects ISSN: 2349-7688, Special Issue: Concientious and Unimpeachable Technologies, pp. 8-13. https: / / ww w.ijrra.net / ICCUT2016/ICCUT2016_07.pdf

McAdams, D.P. (2017) Life-Story Approach to Identity. In: Zeigler-Hill V., Shackelford T. (eds) Encyclopedia of Personality and Individual Differences. Springer, Cham. https://doi. org/10.1007/ 978-3-319-28099-8

Nothomb, A. (1999). Stupeur et Tremblements. Paris: Albin Michel.

Oyserman, D., Elmore, K.,\& Smith, G. (2012). Self Identity. In: Mark R. Leary dan June Price Tangney (eds). Handbook of Self and Identity. New York, USA: The Guilford Press.

Papalia, D. E., Olds, S. W., \& Feldman, R. D. (2001). Human Development, 8th edition. NY, USA: McGraw-Hill Higher Education.

Payot, M. (2018). Entretien avec Amélie Nothomb. Bibliothèque publique d'information. https://www.

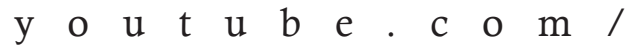
watch?v=R4kLzxbZyWc

Rogers CA. (1959) Theory of Therapy, Personality and Interpersonal Relationships as Developed in the Client-centered Framework. In: S Koch, ed. Psychology: A Study of a Science. Vol. 3: Formulations of the Person and the Social Context. New York: McGraw-Hill.

Sayuti, S.A., Wiyatmi., \& Budiyanto, D. (2019). Membaca NilaiKemanusiaan Dalam Novel Autobiografi. Diksi, Volume 27, Nomor 1, Maret 2019. Retreived from journal.uny.ac.id Simpson, P. (2009). On The Discourse of Satire. PA, USA: John Benjamin Publishing. 
Schultz, D.P., \& Schultz, S.E. (2009). Theories of Personality, 9th eds. CA, USA: Wadsworth.

Soares, C. (2012). Dissociation Mental de la Réalite : Extension du Domaine de la Lutte vs Stupeur et Tremblements. Intercâmbio porto iss 5 , 2012 : 189 - 203. Retrieved 10 september 2019 from https:// search.proquest.com.ezproxy.uny. ac.id/docview/ 2185917955/ 5D2 62C1CBD27427EPQ/1?account id $=31324$
Sylvester, K. (n.d.a) Lironie de l'impuissance dans Stupeur et tremblements : une satire de l'entreprise japonaise. Retrieved February 17th, 2020 from http://artsites.uottawa. ca/luciejoubert/doc/KatelynSylvester.pdf

Wellek, R., \& Warren, A. (1993). Teori kesusastraan. Jakarta: Gramedia.

https://www.livredepoche.com/auteur/ Amélie-nothomb www.amélie-nothomb.com 